\title{
EFFECT OF METAL ION Cu (II) and Mg (II) ON THE ACTIVITIES ANTIOXIDANT ANTHOCYANIN OF EXTRACT ETHANOL SKIN DRAGON FRUIT RED(Hylocereuspolyrhizus)
}

\author{
Asrul Sani ${ }^{1 *}$, Ahyar Ahmad ${ }^{2}$, Firdaus $^{2}$ \\ ${ }^{1}$ Laboratory of Biochemistry Department of Chemistry, Faculty of Science, University of Hasanuddin \\ ${ }^{2}$ Department of Chemistry, Faculty of Mathematics and Natural Sciences, Hasanuddin University, Jl. Perintis \\ Kemerdekaan Km. 10 Tamalanrea, Makassar, Indonesia 90245 \\ E-mail: arul7395@yahoo.co.id
}

\begin{abstract}
Abstrak.Penelitian mengenai pengaruh ion logam $\mathrm{Cu}^{2+}$ dan $\mathrm{Mg}^{2+}$ terhadap aktivitas antioksidan antosianin dari ekstrak etanol kulit buah naga merah (Hylocereus polyrhizus) telah dilakukan. Penelitian ini dilakukan melalui tahap ekstraksi dan identifikasi senyawa pigmen antosianin dari ekstrak etanol kulit buah naga merah, penentuan kadar dan aktivitas antioksidan antiosianin dari kulit buah naga merah dengan pelarut etanol, serta pengaruh ion logam $\mathrm{Cu}^{2+}$ dan $\mathrm{Mg}^{2+}$ terhadap aktivitas antioksidan antosianin. Identifikasi senyawa antosianin dilakukan dengan uji identifikasi warna, serta dianalisis dengan menggunakan spektrofotometer UV-Vis dan FTIR. Penentuan kadar antosianin menggunakan metode perbedaan $\mathrm{pH}$, dan penentuan pengaruh ion logam dilakukan dengan menambahkan masing-masing 50 ppm, 100 ppm, dan 150 ppm logam $\mathrm{Cu}^{2+}$ dan $\mathrm{Mg}^{2+}$ ke dalam ekstrak antosianin yang telah diasamkan dengan $\mathrm{HCl}$, dianalisis dengan spektrofotometer FTIR. Uji aktivitas antioksidan menggunakan metode DPPH. Hasil penelitian menunjukkan ekstrak etanol kulit buah naga merah positif mengandung antosianin dengan kadar sebesar $12,5241 \mathrm{mg} / \mathrm{L}$ dan aktivitas antioksidan $\left(\mathrm{IC}_{50}\right)$ sebesar $0,478 \mu \mathrm{g} / \mathrm{mL}$ serta dengan penambahan ion logam $\mathrm{Cu}^{2+}$ dan $\mathrm{Mg}^{2+}$ dapat meningkatkan aktivitas antioksidan $\left(\mathrm{IC}_{50}\right)$ antosianin menjadi $0,2259 \mu \mathrm{g} / \mathrm{mL}$ untuk $\mathrm{Cu}^{2+}$ pada konsentrasi $50 \mathrm{ppm}$ dan $0,3351 \mu \mathrm{g} / \mathrm{mL}$ untuk $\mathrm{Mg}^{2+}$ pada konsentrasi $50 \mathrm{ppm}$.
\end{abstract}

Kata kunci: Kulit buah naga merah, antosianin, $\mathrm{Cu}^{2+}, \mathrm{Mg}^{2+}$, antioksidan.

Abstract.The effect of $\mathrm{Cu}^{2+}$ and $\mathrm{Mg}^{2+}$ metal ions on the antioxidant activity of anthocyanins of ethanol extract from the red dragon skin fruit (Hylocereus polyrhizus) has been done. Anthocyanin pigments from ethanol extract the red dragon skin fruit, content and antioxidant activity of anthocyanins from the red dragon fruit skin with ethanol solvent, and the effect of $\mathrm{Cu}^{2+}$ and $\mathrm{Mg}^{2+}$ metal ions on the antioxidant activity of anthocyanins. Identification of anthocyanin was done by identification of color test, using spectrophotometer analysis of UV-Vis and FTIR. The anthocyanin content was determined using $\mathrm{pH}$ difference method, and determined effect of metal ions extract was done by adding $50 \mathrm{ppm}, 100 \mathrm{ppm}$, and $150 \mathrm{ppm}$ of metal ions $\mathrm{Cu}^{2+}$ and $\mathrm{Mg}^{2+}$ into the anthocyanin extract that was been acidified by $\mathrm{HCl}$, using spectrophotometer analysis of FTIR. Antioxidant activity test using DPPH method. The results show that ethanol extracts the red dragon anthocyanin by content is $12.5241 \mathrm{mg} / \mathrm{L}$ and antioxidant activity (IC $\mathrm{I}_{50}$ ) is $0.478 \mu \mathrm{g} / \mathrm{mL}$ and with addition of ${ }^{2+}$ and $\mathrm{Mg}^{2+}$ metal ions can be increased antioxidant activity ( $\mathrm{IC}_{50}$ ) of anthocyanins to be $0.2259 \mu \mathrm{g} / \mathrm{mL}$ for $\mathrm{Cu}^{2+}$ at concentration $50 \mathrm{ppm}$ and $0.3351 \mu \mathrm{g} / \mathrm{mL}$ for $\mathrm{Mg}^{2+}$ at concentration $50 \mathrm{ppm}$.

Keywords: The red dragon skin fruit, anthocyanin, $\mathrm{Cu}^{2+}, \mathrm{Mg}^{2+}$, antioxidant. 


\section{INTRODUCTION}

Degenerative diseases are often found in the community, including cancer, tumors, heart disease, stroke, diabetes, liver, and others. The cause of degenerative diseases, one of which is due to lack of antioxidants that can neutralize free radicals contained in the body

Free radicals can come from outside the body in the form of foods that contain lots of preservatives, dyes, unsaturated fatty acids, pesticides, pollution, dust, and radiation ultraviolet. The emission of motorized vehicles, industry, cigarette smoke and the release of reactive chemical compounds into nature is a significant contributor to free radicals. Antioxidants are compounds that can inhibit or neutralize free radicals (Ikhlas, 2013).

Antioxidants can protect the body against damage by reactive oxygen species, can inhibit degenerative diseases and can inhibit lipid peroxide. Plants are a source of natural antioxidants and are generally spread on plant parts, such as wood, seeds, leaves, fruit, skin, roots, and flowers (Ikhlas, 2013).

Red dragon fruit skin contains active compounds, including alcohol, terpenoids, flavonoids, thiamine, anthocyanin, pyridoxine, phenolic, and carotene (Jaafar et al., 2009). According to $\mathrm{Wu}$ et al. (2006), the antioxidant activity found in red dragon fruit skin is higher than antioxidant activity in the fruit flesh, so it has the potential to be developed as a source of natural antioxidants. In addition, antioxidant activity of dragon fruit skin is also supported by research conducted by Mitasari (2012), which states that red dragon fruit skin chloroform extract has antioxidant activity with ICvalue $_{50}$ of $43.836 \mu \mathrm{g} / \mathrm{mL}$.

Anthocyanin is a group of pigments that are red to blue which are scattered in plants. Anthocyanin pigments have biological activities that are beneficial to the health of the body. But along with the length of storage, anthocyanin can be degraded due to the influence of the external environment during storage, such as temperature, light, metal ions, oxygen, water molecules, sugar, and copigmentation (Brouilard, 1982).

One way to increase antioxidant activity in anthocyanins is by complexing metal ions. Anthocyanin is a group of flavonoids with free hydroxyl groups. The presence of more than one hydroxyl group, especially in ring B, will increase its antioxidant activity. Some metals can form complexes with anthocyanins are $\mathrm{Sn}, \mathrm{Cu}, \mathrm{Fe}, \mathrm{Al}, \mathrm{Mg}$, and $\mathrm{K}$ (Miguel, 2011). The structure of anthocyanin is as follows:

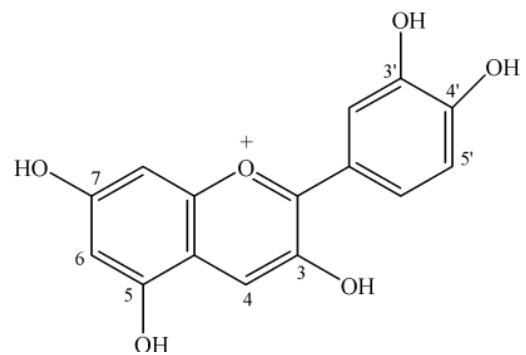

Figure 1. Chemical structure of anthocyanin

Copper metal is one of the essential micronutrients for humans. Copper plays a role in the process of maturation of red blood cells and the process of formation of hemoglobin, and facilitates iron absorption. The benefits of copper in relation to complex compounds have been widely investigated. The importance of copper in the health sector, 
for example as an antiproliferation, anticancer, antitumor agent. In the body itself, copper acts as a co-factor in various enzymatic reactions. Utilization of various metals including copper as forming new complexes with various types of drugs.

Magnesium is one of the most common elements in the human body. There are at least 50\% magnesium ions in human bones, these ions are used in catalyzing enzyme formation. Another role of magnesium is to regulate the active transport of ions such as potassium and calcium through cell membranes. In relation to the transport system, magnesium affects the relationship of nerve impulses, muscle contractions, and normal heart rhythms. Metal magnesium also has a vital role in the body, Mgions ${ }^{2+}$ are a basic component of each cell type (Poedjiadi and Supriyanti, 2009).

\section{RESEARCH METHODS}

This research was conducted in August to October 2017, held at the Ujung Pandang State Polytechnic Chemical Engineering Laboratory, Biochemistry Laboratory, Organic Chemistry Laboratory, and Integrated Chemistry Laboratory, Department of Chemistry, Faculty of Mathematics and Natural Sciences, Hasanuddin University, Makassar.

\section{Sample extraction}

Total of $90 \mathrm{~g}$ of red dragon fruit skin samples that were finely extracted were using maceration techniques using ethanol pa and $1 \% \mathrm{HCl}$ solvents with a volume ratio of 9: 1 as much as $200 \mathrm{~mL}$. Maseration is carried out for 24 hours 3 times, then filtered and the filtrate is collected in a dark vial bottle. The residue is extracted again with the same solvent with a magnetic stirrer until the banana heart is pale (perfectly extracted). The filtrate was put together and concentrated using a rotary vacuum evaporator so that a concentrated ethanol extract was then weighed, calculated by its renditions (Suzery et al., 2010).

\section{Identification of Anthocyanin Pigments} Identification was carried out by testing the color reaction using $\mathrm{HCl}$ and $\mathrm{NaOH}$ solvents, identification with UV-Vis spectrophotometer and FT-IR.

\section{Total Anthocyanin Level Analysis}

Two sample extract solutions were prepared from each filtrate, the first sample used a $\mathrm{pH} 1$ solution and for the second sample a $\mathrm{pH} 4.5$ solution was used. Each sample was dissolved based on dilution factors. Let stand for a few minutes before being measured using a UV-Vis spectrophotometer. Absorbance of each solution at the maximum wavelength and wavelength of $700 \mathrm{~nm}$, measured by a solution of $\mathrm{pH} 1$ and $\mathrm{pH} 4.5$ as the blank. The total anthocyanin level can be calculated using the formula in equation (Putri et al., 2015):

$$
\mathrm{A}=\left(\mathrm{A}_{\lambda \max }-\mathrm{A}_{700}\right)_{\mathrm{pH}} 1.0-\left(\mathrm{A}_{\lambda \max }-\mathrm{A}_{700}\right)_{\mathrm{pH}} 4.5
$$

Total Anthocyanin (mg / L) :

$$
\text { A x BM x DF x } 1000 / \text { exl }
$$

Ket.

$\mathrm{BM}=$ molecular weight of cyanidin-3glucoside $(449.2 \mathrm{~g} / \mathrm{mol})$

$\mathrm{DF}=$ dilution factor 
e $=$ molar absorptivity cyanidin-3glucoside (26,900 L / (mol.cm))

$1=$ thick cuvette $(1 \mathrm{~cm})$

\section{Complexation of Extracts Anthocyanin with Metal Ions The}

Production of an anthocyanin extract complex with metal ions is done by taking 50 $\mathrm{mL}$ of red dragon fruit skin extract into a beaker, then adding $1 \mathrm{~N} \mathrm{HCl}$ to $\mathrm{pH} 3$ while stirring using a magnetic stirrer. The solution was pipetted $10 \mathrm{~mL}$ into different erlenmeyer containing metal ions $\mathrm{Cu}$ (II) and $\mathrm{Mg}$ (II) 0 ppm, $50 \mathrm{ppm}, 100 \mathrm{ppm}$ and $150 \mathrm{ppm}$ respectively. The work was carried out in a place protected from sunlight then analyzed by FTIR spectrophotometer (Abdillah, 2014).

\section{Antioxidant Activity Test with DPPH Method}

The mother solution of anthocyanin extract was made at a concentration of 1000 $\mathrm{ppm}$. From the mother liquor a concentration series of 0.1 is made; $0.2 ; 0.3 ; 0.4$; and 0.5 ppm by piping the mother liquor consecutively $0.4 ; 0.8 ; 1,2 ; 1.6$; and $2 \mathrm{~mL}$. DPPH solution was added as much as $1 \mathrm{~mL}$, and the volume was up to $5 \mathrm{~mL}$ with methanol pa and as a comparison used anthocyanin extract complex with metal ions $\mathrm{Cu}$ (II), anthocyanin extract complex with metal ions $\mathrm{Mg}$ (II), and ascorbic acid. The mixture is shaken and left for 30 minutes at room temperature and in a room protected from sunlight. Absorbance (A) was measured using a UV-Vis spectrophotometer at maximum wavelength. Next is the percentage of inhibition (resistance) and ICinhibition $_{50}(50 \%$ concentration $)$. To calculate IC values50 percent inhibition data from the tests performed (Molyneux, 2004) is needed.

\section{RESULTS AND DISCUSSION}

Anthocyanin extraction from Red Dragon Fruit Skin (Hylocereus polyrhizus)

The extraction of 90 grams of red dragon fruit skin sample obtained 31,3296 grams of thick red extract. With the ethanol extract rendition obtained at $34.8106 \%$.

\section{Identification of Anthocyanin Pigment}

\section{Identification with Color Reaction}

The color identification results from the ethanol extract of red dragon fruit skin that was previously red showed that the addition of $\mathrm{HCl}$ produced red color while after addition $\mathrm{NaOH}$ produced a bluish green color, and the results obtained showed the presence of anthocyanin compounds. One of the factors that affect the color of anthocyanin is the condition of acids and bases. The nature of the acid will cause the color of anthocyanin to red, while the nature of the base causes the anthocyanin to become bluish green.

\section{Identification with Uv-Vis Spectrophotometer}

Data from UV-Vis spectrophotometer measurements on ethanol extract of red dragon fruit skin are shown in Figure 2. The spectral pattern in Figure 2 shows the maximum wavelength of ethanol extract of red dragon fruit skin obtained is $500.4 \mathrm{~nm}$, so the yield which is obtained according to the characteristics of the maximum anthocyanin wavelength and can be said to be red dragon fruit peel extract containing anthocyanin compounds. 


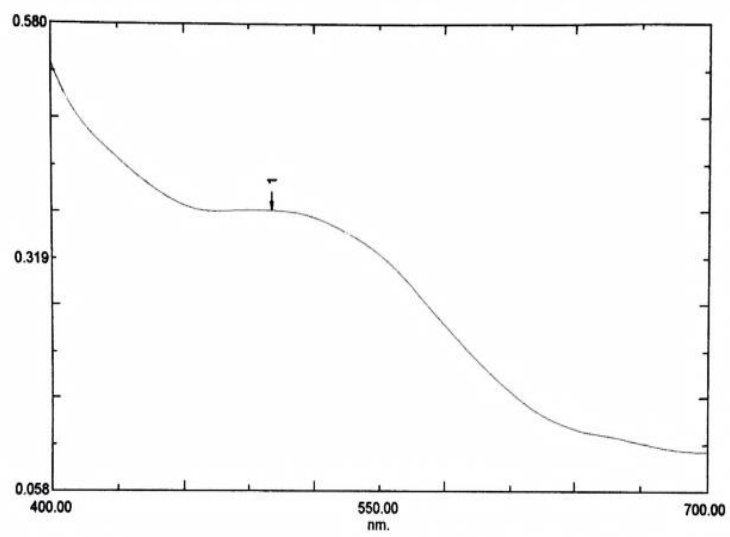

Figure 2. Maximum wavelength $\left(\Lambda_{\max }\right)$ of red dragon fruit skin ethanol extract

\section{Identification with FTIR}

The spectrum of analysis results by spectrophotometer FTIR ethanol extract of red dragon fruit skin shown in the results of the analysis is presented in table 1.

Table 1. Anthocyanin wave numbers by FTIR analysis of

\begin{tabular}{|c|c|c|c|}
\hline \multicolumn{3}{|c|}{ Number wave $\left(\mathrm{cm}^{-1}\right)$ FTIR absorption band } & \multirow{2}{*}{$\begin{array}{l}\text { Function } \\
\text { group }\end{array}$} \\
\hline $\begin{array}{c}\text { Image spectrum } \\
8 .\end{array}$ & $\begin{array}{c}\text { Previous research } \\
\text { (Maulina dkk., 2014) }\end{array}$ & $\begin{array}{c}\text { Literature } \\
\text { (Stuart, 2004) }\end{array}$ & \\
\hline 3412,08 & 3348,25 & $3500-3000$ & $-\mathrm{OH}$ \\
\hline 1215,15 & 1044,35 & $1300-1000$ & -C-O alkohol \\
\hline 1512,19 & 1634,95 & $1650-1450$ & $-\mathrm{C}=\mathrm{C}-$ aromatik \\
\hline 1724,36 & 1706,30 & $1700-16980$ & $-\mathrm{C}=\mathrm{O}$ \\
\hline
\end{tabular}

Based on the results of the FTIR spectrum it can be concluded that the thick extract obtained contains anthocyanin compounds. However, the obtained FTIR spectrum shows many other spectra that emerge. This is because the sample used is crude extract, not

Samples were measured at the maximum wavelength and wavelength of $700 \mathrm{~nm}$. Determination of the maximum wavelength of the extract obtained wavelength of $500.4 \mathrm{~nm}$. While the wavelength of $700 \mathrm{~nm}$ is to correct deposits that are still present in the sample. If the sample is really clear, the absorbance at yet in its pure form, so that the absorption of functional groups of compounds other than anthocyanin still appears.

\section{Total Anthocyanin Level Analysis}

$700 \mathrm{~nm}$ is zero. However, in this study the absorbance value at a wavelength of $700 \mathrm{~nm}$ does not give a zero value, this is due to the presence of small particles in the sample. The anthocyanin content of ethanol extract of red dragon fruit skin can be seen in Table 2. 
Table 2. Total anthocyanin content of ethanol extract of red dragon fruit peel

\begin{tabular}{|c|c|c|c|c|}
\hline \multicolumn{4}{|c|}{ Absorbance of } & \multirow{3}{*}{$\begin{array}{l}\text { Total Anthocyanin } \\
(\mathrm{mg} / \mathrm{L})\end{array}$} \\
\hline \multicolumn{2}{|c|}{ pH 1} & \multicolumn{2}{|c|}{ pH 4.5} & \\
\hline $\begin{array}{c}\lambda 500.4 \\
\mathrm{~nm}\end{array}$ & $\begin{array}{c}\lambda 700 \\
\mathrm{~nm}\end{array}$ & $\begin{array}{c}\lambda \mathbf{5 0 0 . 4} \\
\mathrm{nm}\end{array}$ & $\begin{array}{c}\lambda \mathbf{7 0 0} \\
\mathbf{n m}\end{array}$ & \\
\hline 0.374 & 0.102 & 0.251 & 0.054 & 12.5241 \\
\hline
\end{tabular}

In determining the anthocyanin level, the sample dilution factor must be determined first by dissolving the sample in $\mathrm{pH} 1 \mathrm{HCl}$ solution so that absorbance is less than 1.2 at the maximum wavelength. The predetermined dilution factor is 10 dilutions with absorbance of $0.374 \mathrm{~nm}$. Based on the calculation results, the total anthocyanin level is $12.5241 \mathrm{mg} / \mathrm{L}$ on average.

\section{Complexation of Anthocyanine Extracts Figure 3} with $\mathrm{Cu}$ (II) and Mg (II) Metal Ions
Complex identification of anthocyanin compounds with Cumetal ions $2+$ and $\mathrm{Mg} 2+$ can be traced using FTIR data. This is because in the anthocyanin structure there is resonance which can make $\mathrm{O}$ atoms become uncharged, namely resonance by $\mathrm{OH}$ on carbon numbers 5.7, and 4 '. FTIR spectra of ethanol extract of red dragon fruit skin as a control and anthocyanin complex with metal ions $\mathrm{Cu}$ (II) and $\mathrm{Mg}$ (II) at a concentration of $150 \mathrm{ppm}$ are presented in

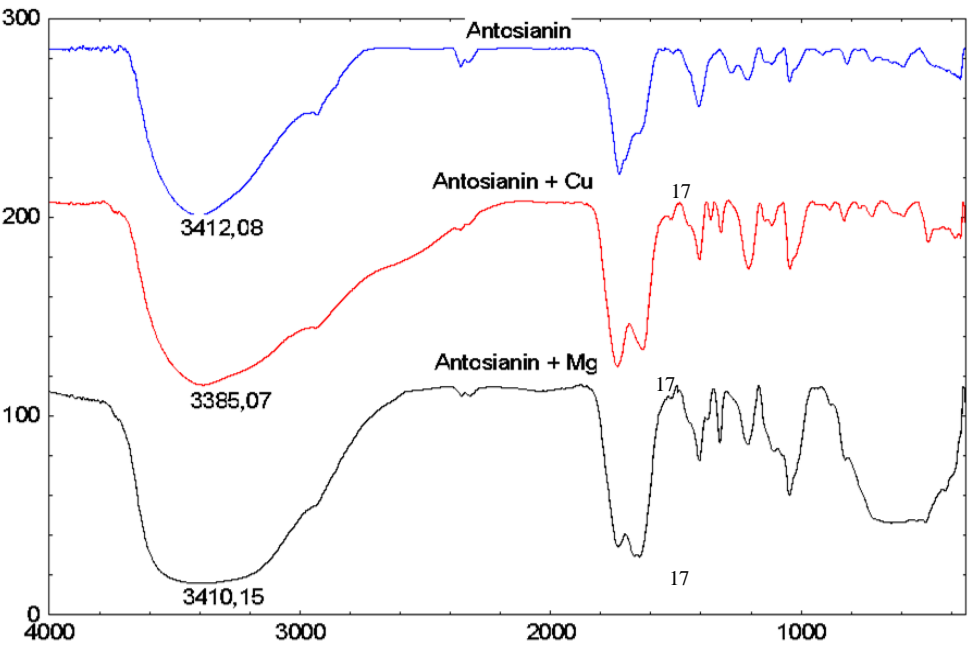

Figure 3. Comparison of functional groups found in anthocyanin and complex extracts anthocyanin with Cumetal ions ${ }^{2+}$ and $\mathrm{Mg}^{2+}$ at a concentration of $150 \mathrm{ppm}$

FTIR spectrum from the anthocyanin The value of wave number before addition of extract of red dragon fruit skin before and after metal is $3412.08 \mathrm{~cm}^{-1}$, and after addition of the addition of metals shows a shift in wave Cumetal ions ${ }^{2+}$ and $\mathrm{Mg}^{2+}$ has a shift to 3385.07 numbers especially in the $-\mathrm{OH}$ function group. $\mathrm{cm}^{-1}$ and $3410.15 \mathrm{~cm}^{-1}$. Whereas in the 
functional group $\mathrm{C}=\mathrm{O}$ the value of the wave number before the addition of metal is 1724.36 $\mathrm{cm}^{-1}$, and after the addition of $\mathrm{Cu}^{2+}$ and $\mathrm{Mg}^{2+}$ has shifted to $1734.01 \mathrm{~cm}^{-1}$ and $1730.15 \mathrm{~cm}^{-1}$. The formation of complexes with metals at positions 3 'and 4' indicates the occurrence of resonance from $-\mathrm{OH}$ at positions 5 and 7 (monomers) and causes the $\mathrm{OH}$ bond to weaken. In the FTIR spectrum, it is also seen that the $\mathrm{OH}$ absorption wave number in the $\mathrm{Cu}$ complex is weaker than the $\mathrm{Mg}$ complex, so it can be stated that the $\mathrm{Cu}$ complex is more stable than the $\mathrm{Mg}$ complex. This is because the smaller the value of the wave number on $\mathrm{OH}$ absorption, the bond is weaker due to the ease of resonance towards the $\mathrm{C}=\mathrm{O}$ group, so that the formation of $\mathrm{Cu}$ complex bonds is stronger and produces a more stable complex, as shown in Figure 4.<smiles></smiles>

Figure 4. Estimates of the structure of metal complexes with anthocyanins

(Ahmed et al., 2013)

\section{Analysis of Antioxidant Activities with DPPH Method}

The antioxidant activity test was carried out using the DPPH method. This test was conducted to determine the ability of compounds to counteract free radicals, in this study carried out on ethanol extract of red dragon fruit skin, namely the treatment before and after the addition of Cumetal ions ${ }^{2+}$ and $\mathrm{Mg}^{2+}$ to anthocyanins.

Table 3. The antioxidant activity of ethanol extract of red dragon fruit peel

\begin{tabular}{cccccc}
\hline Sample & $\begin{array}{c}\text { Concentratio } \\
\mathbf{n}(\mathbf{p p m})\end{array}$ & Absorbace & \% Inhibition & $\begin{array}{l}\text { Linear } \\
\text { Regression } \\
\text { Equation }\end{array}$ & $\begin{array}{c}\text { IC } \mathbf{5 0} \\
(\boldsymbol{\mu g} / \mathbf{m L})\end{array}$ \\
\cline { 1 - 4 } Antosianin & 0,1 & 0,242 & 14,1844 & & \\
dari ekstrak & 0,2 & 0,205 & 27,3049 & & \\
etanol kulit & 0,3 & 0,178 & 36,8794 & $+8,4043$ & 0,478 \\
buah naga & 0,4 & 0,154 & 45,3900 & & \\
merah & 0,5 & 0,145 & 48,5815 & & \\
\hline
\end{tabular}

The maximum wavelength of DPPH used is at a wavelength of $515 \mathrm{~nm}$. The test results of antioxidant activity obtained can be seen in Table 4 . 
Table 4. Antioxidant activity of ascorbic acid as a positive control

\begin{tabular}{cccccc}
\hline Sample & $\begin{array}{c}\text { Concentration } \\
(\mathbf{p p m})\end{array}$ & Absorbance & $\begin{array}{c}\text { \% } \\
\text { Inhibition }\end{array}$ & $\begin{array}{c}\text { Linear } \\
\text { Regression } \\
\text { Equation }\end{array}$ & $\begin{array}{c}\mathbf{I C}_{\mathbf{5 0}} \\
(\boldsymbol{\mu g} / \mathbf{m L})\end{array}$ \\
\hline \multirow{4}{*}{ Asam } & 1 & 0,433 & 11,8136 & & \\
askorbat & 2 & 0,293 & 40,3258 & & \\
& 3 & 0,190 & 61,3034 & $\mathrm{y}=19,73 \mathrm{x}-2,301$ & 2,6508 \\
& 4 & 0,094 & 80,8554 & & \\
\hline
\end{tabular}

From the above data it can be concluded that red dragon fruit skin anthocyanin has stronger antioxidant activity than positive control, namely ascorbic acid. The IC value of 50 red dragon fruit skin extract was obtained 0.478 $\mu \mathrm{g} / \mathrm{mL}$, while theICvalue 50 strongestmetalwas the anthocyanin extract complex with $\mathrm{Cu}$ metal ions at a concentration of $50 \mathrm{ppm}$ at 0.2259 $\mu \mathrm{g} / \mathrm{mL}$ while for the anthocyanin extract complex with metal ions $\mathrm{Mg}$ is at a concentration of $50 \mathrm{ppm}$ of $0.3351 \mu \mathrm{g} / \mathrm{mL}$. so that the level of antioxidant strength of the sample and comparison can be seen in Table 5.

Table 5. IC value of 50 and the antioxidant strength of red dragon fruit skin extract and anthocyanin extract complex with metal ions and comparator (positive control)

\begin{tabular}{ccc}
\hline samples / comparators & IC $_{50}$ & intensity \\
\hline & Sample & \\
\hline Anthocyanin extract & $0.478 \mu \mathrm{g} / \mathrm{mL}$ & Very Strong \\
Cu-anthocyanin 50 ppm & $0.2259 \mu \mathrm{g} / \mathrm{mL}$ & Very Strong \\
Cu-anthocyanin 100 & & \\
ppm & $0.2282 \mu \mathrm{g} / \mathrm{mL}$ & Very Strong \\
Cu-anthocyanin 150 & $0.2335 \mu \mathrm{g} / \mathrm{mL}$ & Very Strong \\
ppm & & \\
$\mathrm{Mg}$-anthocyanin 50 ppm & $0.3351 \mu \mathrm{g} / \mathrm{mL}$ & Very Strong \\
Mg-anthocyanin 100 & & \\
ppm & $0.4030 \mu \mathrm{g} / \mathrm{mL}$ & Very Strong \\
Mg-anthocyanin 150 & $0.5077 \mu \mathrm{g} / \mathrm{mL}$ & VeryStrength \\
ppm & \\
\hline \multicolumn{2}{c}{ Comparative(Positive Control) } \\
\hline Ascorbic Acid & $2.6508 \mu \mathrm{g} / \mathrm{mL}$ & Very strong \\
\hline
\end{tabular}




\section{CONCLUSION}

Based on the research that has been done can be concluded that the ethanol extract of red dragon fruit positive skin containing compounds anthocyanin pigments. The total anthocyanin content in the ethanol extract of red dragon fruit skin was $12.5241 \mathrm{mg} \mathrm{/} \mathrm{L.}$ Anthocyanin extract from red dragon fruit skin has very strong antioxidant activity with

\section{REFERENCES}

Abdilah, F., 2014, Characterization, Toxicity and Antioxidant Test of Metal Complexes $\mathrm{Cu}$ (II), Zn (II) and Co (II) Chlorophyll Derivatives from Fitoplanton Extract, Unpublished Thesis, Faculty of Mathematics and Natural Sciences, Hasanuddin University, Makassar.

Ahmed, JK, Salih, HAM, and Hadi, AG, 2013, Anthocyanins in Red Beet Juice Act as Scavengers for Heavy Metals such as Lead and Cadmium, International Journal of Science and Technology, 2(3): 269-274.

Bukhari, SB, Memon, MM, Tahir, MI, and Bhanger, I ,. 2009, Synthesis, Characterization and Antioxidant Activity of Copper-Quercetin Complex., Spectrochim Acta Part A, 71: 1901-1906.

Jaafar, Ali, R., Nazri, M., and Khairuddin, W., 2009, Proximate Analysis of Dragon Fruit (Hylecereus polyhizus), American Journal of Applied Sciences, 6(1): 13411346.

Molyneux, P., 2004, The Use of Stable Free Radical Diphenylpicrylhydrazyl (DPPH) for Estimating Antioxidant Activity, Songklanakarian J. Sci. Technol, 26(2): 211-219.

Poedjiadi, A., and Supriyanti, FMT, 2009. Basics of Biochemistry, revised edition, UI-Press, Indonesia.

Putri, NKM, Gunawan, IWG, and Suarsa, IW, 2015, Anthocyanin Antioxidant Activity in Ethanol Extract of Super Red Dragon
ICvalue 50 of $0.478 \mu \mathrm{g} / \mathrm{mL}$. The anthocyanin complexation antioxidant activity with Cumetal ions2+ and $\mathrm{Mg} 2+$ at concentrations of 50, 100, and $150 \mathrm{ppm}$ was the most powerful in anthocyanin complexation with the addition of Cumetal ions $2+$ at a concentration of $50 \mathrm{ppm}$ which was equal to $0.2259 \mu \mathrm{g} / \mathrm{mL}$.

Fruit Skin (Hylocereus costaricensis) and Total Level Analysis, Chemical Journal, 9(2): 243-251.

Suzery, M., Lestari, S., and Cahyono, B., 2010, Determination of Total Anthocyanin from Rosela Flower Petals (Hibiscus sabdariffa L) with Maseration and Sokshletasi Method, Journal of Science and Mathematics, 18(1): 1-6. 